\title{
Optimization of a new flow design for solid oxide cells using computational fluid dynamics modelling
}

Duhn, Jakob Dragsbæk; Jensen, Anker Degn; Wedel, Stig; Wix, Christian

Published in:

Journal of Power Sources

Link to article, DOI:

10.1016/j.jpowsour.2016.10.060

Publication date:

2016

Document Version

Peer reviewed version

Link back to DTU Orbit

Citation (APA):

Duhn, J. D., Jensen, A. D., Wedel, S., \& Wix, C. (2016). Optimization of a new flow design for solid oxide cells using computational fluid dynamics modelling. Journal of Power Sources, 336, 261-271.

https://doi.org/10.1016/j.jpowsour.2016.10.060

\section{General rights}

Copyright and moral rights for the publications made accessible in the public portal are retained by the authors and/or other copyright owners and it is a condition of accessing publications that users recognise and abide by the legal requirements associated with these rights.

- Users may download and print one copy of any publication from the public portal for the purpose of private study or research.

- You may not further distribute the material or use it for any profit-making activity or commercial gain

- You may freely distribute the URL identifying the publication in the public portal 


\title{
Optimization of a new flow design for Solid Oxide Cells using Computational Fluid Dynamics modelling
}

\author{
Jakob Dragsbæk Duhn ${ }^{\mathrm{ab}^{*}}$, Anker Degn Jensen ${ }^{\mathrm{a}}$, Stig Wedel ${ }^{\mathrm{a}}$ and Christian Wix ${ }^{\mathrm{b}}$. \\ aDepartment of Chemical and Biochemical Engineering, Technical University of Denmark, Building 229, DK- \\ 2800 Kgs. Lyngby, Denmark

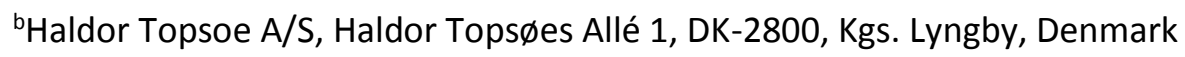 \\ *Corresponding author. Tel +45 22476700, Fax +45 45882258, E-mail address: JADU@kt.dtu.dk \\ Keywords: Solid Oxide Cell; Flow distribution; Fuel utilization rate; Planar fuel cells; Geometry optimization; \\ Parallel channels
}

\begin{abstract}
Design of a gas distributor to distribute gas flow into parallel channels for Solid Oxide Cells (SOC) is optimized, with respect to flow distribution, using Computational Fluid Dynamics (CFD) modelling. The CFD model is based on a $3 \mathrm{~d}$ geometric model and the optimized structural parameters include the width of the channels in the gas distributor and the area in front of the parallel channels. The flow of the optimized design is found to have a flow uniformity index value of 0.978. The effects of deviations from the assumptions used in the modelling (isothermal and non-reacting flow) are evaluated and it is found that a temperature gradient along the parallel channels does not affect the flow uniformity, whereas a temperature difference between the channels does. The impact of the flow distribution on the maximum obtainable conversion during operation is also investigated and the obtainable overall conversion is found to be directly proportional to the flow uniformity. Finally the effect of manufacturing errors is investigated. The design is shown to be robust towards deviations from design dimensions of at least $\pm 0.1 \mathrm{~mm}$ which is well within obtainable tolerances.
\end{abstract}

\section{Introduction}

Solid oxide cells $(\mathrm{SOC})$ are electrochemical systems capable of operating in fuel cell mode (solid oxide fuel cell - SOFC) and electrolyzer mode (solid oxide electrolyzer cell - SOEC). In SOFC mode hydrogen, carbon monoxide, or hydrocarbons are oxidized, thereby generating electricity, whereas, in SOEC mode, water or carbon dioxide are reduced to fuels/chemicals by consuming electricity.

Solid oxide cells are considered a promising energy technology because of their high theoretical efficiency (due to the high operating temperature of 850 to $1200 \mathrm{~K}$ ) in both SOFC and SOEC mode [1]. In order to 
achieve the high theoretical efficiency, the flow in the cells must be close to uniform. If the flow is not uniform, the conversion in some channels/areas of the cell will be higher than others. If the SOFC is running on hydrogen, Ni might oxidize to NiO due to high local concentrations of water [2]. In SOEC mode, during $\mathrm{CO}_{2}$-electrolysis or $\mathrm{CO}_{2} / \mathrm{H}_{2} \mathrm{O}$ co-electrolysis, carbon might be formed via the Boudouard reaction due to high local concentrations of $\mathrm{CO}$ [3]. Additionally, a non-uniform flow also contributes to thermal stress within the cell since the heat effects of reaction become unevenly distributed [4-6].

The flow in SOCs has been widely studied, with U- and Z-type manifold and parallel channels being favored by most researchers [7-17]. In U- and Z-type SOCs the parallel channels are fed from a single manifold. In U-type flow, the channels nearest the inlet/outlet receive more flow than the channel farthest away from the inlet/outlet. In Z-type flow, the parallel channels nearest and farthest away from the inlet receive roughly the same flow, whereas the center channels will receive a lesser flow than the outer channels [12]. To improve the inherently poor flow distribution with these designs, the cross section of each parallel channel can be changed $[18,19]$ or the manifold geometry can be changed [12].

An alternative design to the U- and Z-types is to have gas inlet/outlet holes in front of the parallel channels and adding barriers that distributes the gas into the parallel channels [20-22]. In this article the flow distribution in a commercial SOC cell design [22] using barriers to distribute the gas flow is investigated and optimized using CFD modelling. The effect of the flow non-uniformity on the maximum overall conversion is also investigated. We show that such a design can be optimized to obtain a more optimal design than achievable by $\mathrm{Z}$ or $\mathrm{U}$ type designs.

Other designs than $\mathrm{U}$ - and Z-type, such as serpentine, interdigitated flows [23,24], subset of U- and Z-type geometries [25] and pin type flow cells [26] has also been investigated in the literature [27-30]. However, the pressure drop in serpentine and interdigitated flow quickly increases to the order of a few bars for larger fuel cells [31,32], and the pressure drop in geometries using subset of $U$ - and Z-type is generally higher than single U- and Z-type [25]. In general parallel channels has the lowest pressure drop [33] and parallel channels are therefore of higher interest than the other designs for SOCs.

For low-temperature fuel cell technologies, like Proton Exchange Membranes (PEM), another important aspect is water management, in order to assure that the fuel cell is not flooded [7,30,34-38]. In this article we have focused on SOCs where water flooding is not an issue, and thus we will not investigate water management in our design.

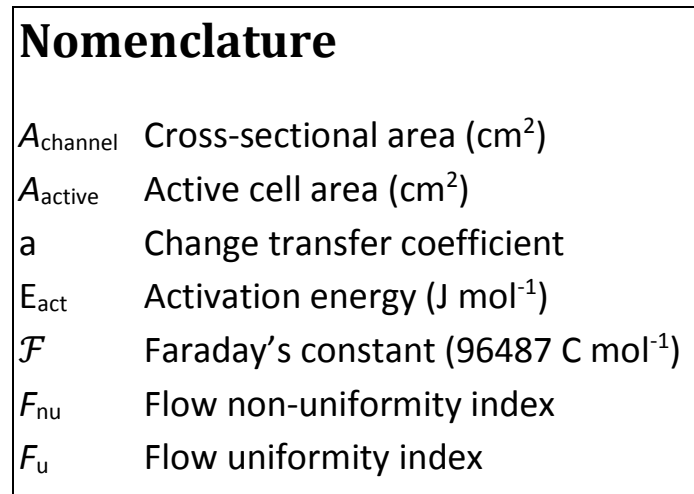




\begin{tabular}{|c|c|}
\hline$h$ & Height of cell (mm) \\
\hline j & Current density $\left(\mathrm{A} \mathrm{cm}^{-2}\right)$ \\
\hline jo & Exchange current density $\left(\mathrm{A} \mathrm{cm}^{-2}\right)$ \\
\hline$M_{i}$ & Molar mass of component i $\left(\mathrm{g} \mathrm{mol}^{-1}\right)$ \\
\hline$\dot{m}$ & Mass flow rate $\left(\mathrm{kg} \mathrm{s}^{-1}\right)$ \\
\hline$N$ & Number of channels \\
\hline$n$ & Number of moles per second $\left(\mathrm{mol} \mathrm{s}^{-1}\right)$ \\
\hline $\mathrm{n}_{\text {act }}$ & Activation overpotential (V) \\
\hline$p$ & Pressure (Pa) \\
\hline$p^{\phi}$ & Pressure at normal conditions (101.325 kPa) \\
\hline$R$ & Universal gas constant $\left(8.3144 \mathrm{~J} \mathrm{~K}^{-1} \mathrm{~mol}^{-1}\right)$ \\
\hline$T^{\phi}$ & Temperature at normal conditions ( $273.15 \mathrm{~K})$ \\
\hline$u$ & Velocity $\left(\mathrm{m} \mathrm{s}^{-1}\right)$ \\
\hline$\dot{v}$ & Volumetric flow rate per time unit $\left(\mathrm{NL} \mathrm{s}^{-1}\right)$ \\
\hline$\ddot{v}$ & Volumetric flow rate per time unit and active cell area $\left(\mathrm{NL} \mathrm{s}^{-1} \mathrm{~cm}^{-2}\right)$ \\
\hline$w_{b}$ & Width of the header before the parallel channels $(\mathrm{mm})$ \\
\hline$w_{c c}$ & Width of the center channel of the distributor $(\mathrm{mm})$ \\
\hline$W_{s c}$ & Width of side channel of the distributor (mm) \\
\hline$x$ & Conversion of the reactant \\
\hline$z$ & Number of electrons transferred \\
\hline$\alpha$ & Ratio of $w_{s c}$ to $w_{c c}$ \\
\hline$\gamma$ & Pre-exponential factor $\left(\mathrm{A} \mathrm{cm}^{-2}\right)$ \\
\hline$\rho$ & Density $\left(\mathrm{kg} \mathrm{m}^{-3}\right)$ \\
\hline$\mu$ & Gas viscosity $\left(\mathrm{kg} \mathrm{m}^{-1} \mathrm{~s}^{-1}\right)$ \\
\hline$\tau$ & Viscous stress tensor $(\mathrm{Pa})$ \\
\hline$\chi_{\mathrm{H}_{2}}$ & Mass fraction of $\mathrm{H}_{2}$ in inlet flow \\
\hline$\Delta \mathrm{P}$ & Pressure drop $(\mathrm{Pa})$ \\
\hline
\end{tabular}

\section{Model description}

\section{$2.1 \quad$ Geometric model}

Figure 1 shows the structure of the SOFC/SOEC cell used in this study. The cell consists of 5 layers: Air electrode, air channel, fuel channel, fuel electrode and electrolyte. An interconnect is placed between the air and fuel channel with the purpose to connect the air and fuel electrode electrically and to distribute the gas evenly to the entire electrode. In this study an interconnect shape with parallel channels is used. Here the gas is divided into the parallel channels, and the ribs ensure electrical contact between the interconnect and the electrode. In this paper we are only concerned with the fuel flow. The fuel channel layer consists of 45 parallel channels, each $1 \mathrm{~mm}$ wide and with a height of $\mathrm{h}=0.3 \mathrm{~mm}$, separated by $1 \mathrm{~mm}$ wide ribs. 
Fuel gas (typically $\mathrm{CH}_{4}$ or $\mathrm{H}_{2}$ in SOFC and $\mathrm{H}_{2} \mathrm{O} / \mathrm{CO}_{2}$ in SOEC) is entering through a manifold of three tubes (which are formed when single cells are assembled to form the stack) to the left in Figure 2, moves through a barrier, hereafter called gas distributor, and is distributed to all the parallel channels (see insert of Figure 1). Purge flow (typically air) is entering through holes at the left side of the cell and exiting through holes at the right side of the cell. In a stack several cells are placed on top of each other, however only the flow in the fuel channel layer is modelled in this study. Furthermore, the flow in the stack manifold (the pipes with in the cell shown in Figure 1) is not included in the model.

Figure 2 shows the geometry of the model implemented in COMSOL 5.1 together with the parameters $w_{s c}$, $w_{c c}, w_{b}$. In order to decrease computational time, the model consists of one third of the cell. The channels are numbered sequentially starting from the bottom. Note that the number of channels on each side of the distributor is not identical. The dimension of the active area is $90 \mathrm{~mm} \times 111 \mathrm{~mm}(\mathrm{H} \mathrm{x} \mathrm{B})$, giving a total active area of $99.9 \mathrm{~cm}^{2}$. The model is a $3 \mathrm{~d}$ model where the height (z-dimension) of the interconnect is $0.3 \mathrm{~mm}$. Previously, $2 \mathrm{~d}$ models with different approximations have been used [8,31,32], while other have applied $3 \mathrm{~d}$ models in order to avoid the uncertainty introduced by the approximations when reducing to a $2 \mathrm{~d}$ model $[11,16,39]$. Since the computational time of our model was relatively low (2-5 minutes on an Intel Xeon E5$2637 \mathrm{CPU}$ with $3.5 \mathrm{GHz}$ ), we only considered the $3 \mathrm{~d}$ model. 


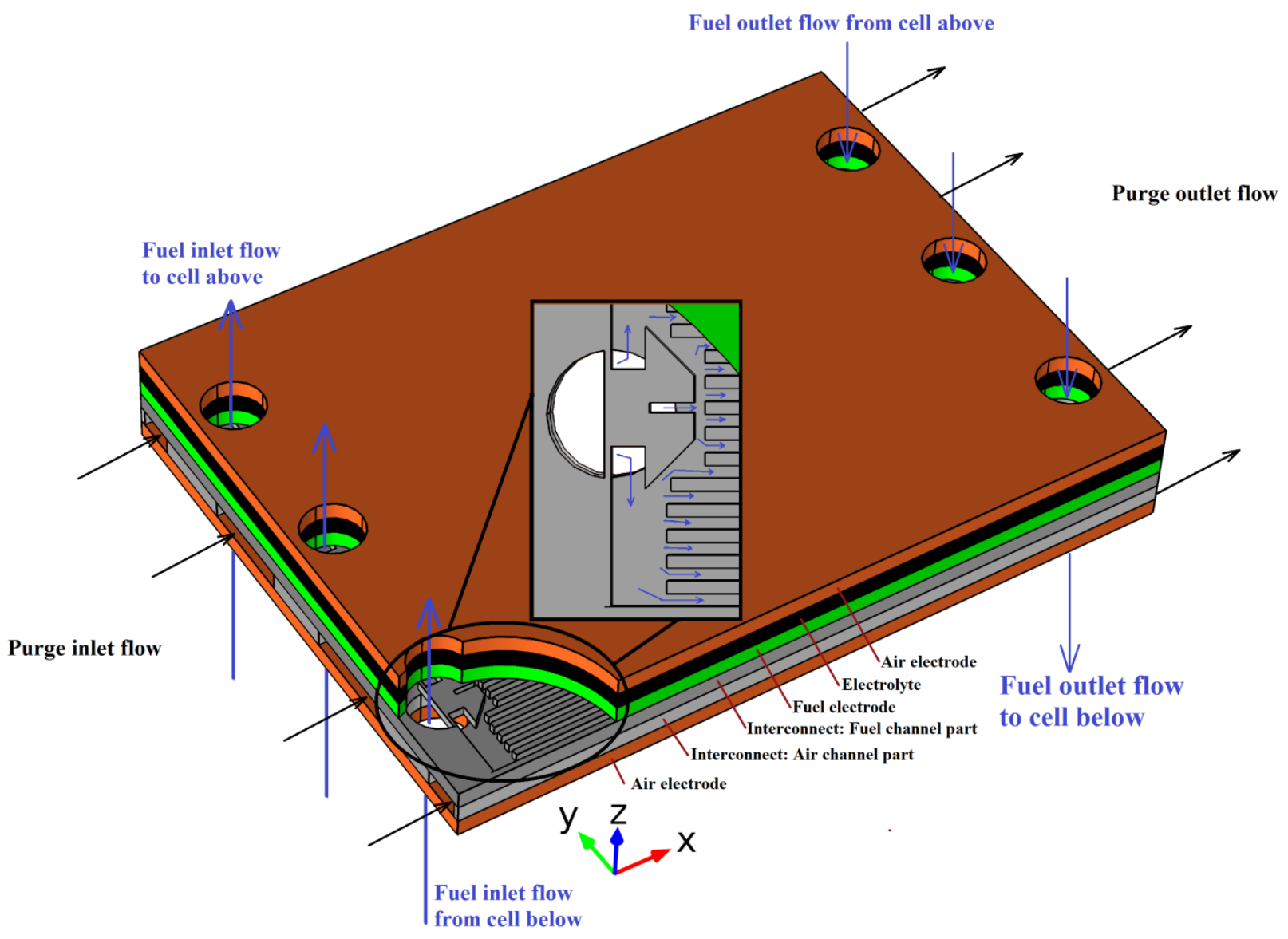

Figure 1: Sketch of the cell geometry. The insert shows the gas distributor and the parallel channels.

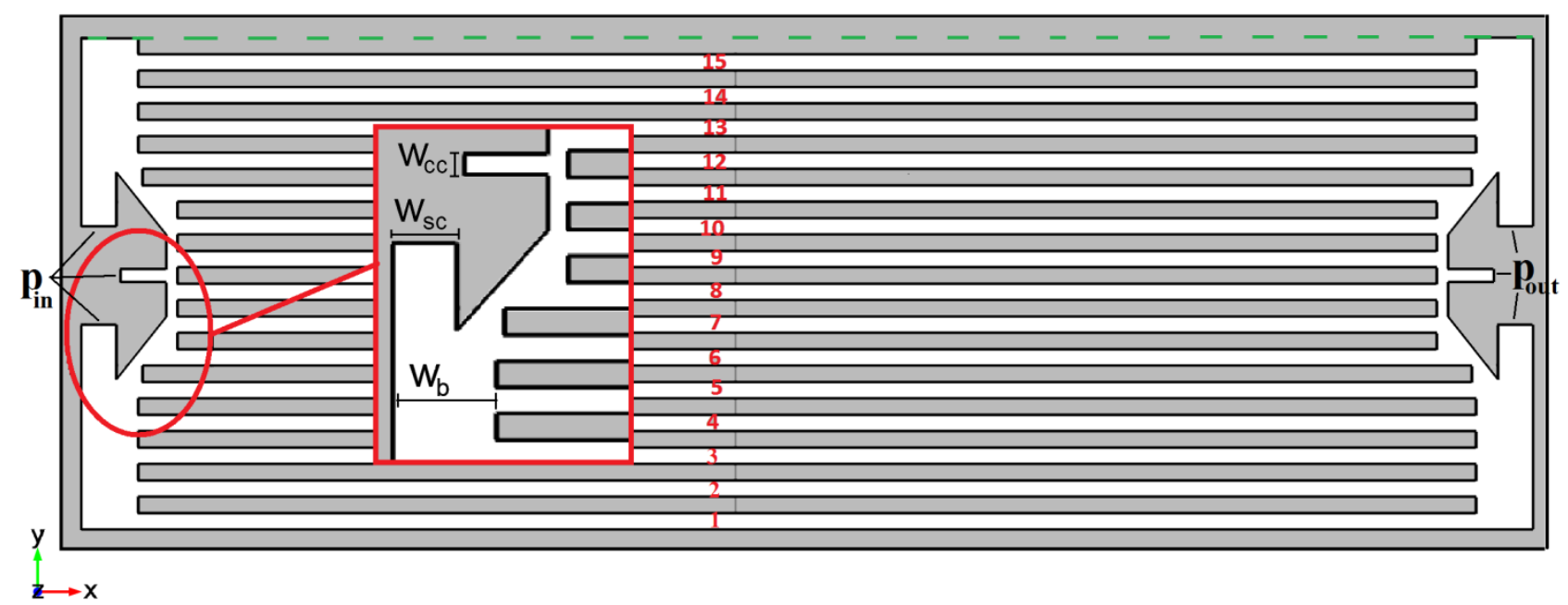

Figure 2. The flow domain modelled in COMSOL. The cross section is extruded $0.3 \mathrm{~mm}$. An inlet pressure, $p_{\text {in, }}$ is applied to the left and an outlet pressure, $p_{\text {out, }}$, to the right. On the dotted horizontal line a symmetry condition is applied.

\section{$2.2 \quad$ Computational methods}

The flow in SOCs under operation is affected by electrochemical reactions and temperature gradients (causing density and viscosity changes). These changes are often disregarded in studies of the flow 
uniformity $[8,32,39,40]$, and we will also assume isothermal and non-reacting incompressible flow. The validity of these assumptions is evaluated in section 3.8 .

\subsubsection{Flow}

The flow is assumed steady and is modelled with the steady state form of the continuity equation and momentum equation:

Continuity equation

$$
\nabla \cdot(\rho u)=0
$$

Momentum equation

$$
\rho(u \cdot \nabla) u=\nabla \cdot(-p I+\tau)
$$

Here $\rho$ is the density, $\mathrm{u}$ is the velocity vector, $p$ is the pressure, $\mathrm{I}$ is the unity tensor, and $\tau$ is the viscous stress tensor. The viscosity and density are fixed at the values of air at $1000 \mathrm{~K}\left(\rho=0.35 \mathrm{~kg} \cdot \mathrm{m}^{-3}, \mu=\right.$ $\left.4.110^{-5} \mathrm{~kg} \cdot \mathrm{m}^{-1} \cdot \mathrm{s}^{-1}\right)$.

\subsubsection{Boundary conditions}

An inlet gauge pressure, $p_{i n}$, of $150 \mathrm{~Pa}$ is specified at the inlet surfaces and on the outlet surfaces a gauge pressure of $p_{\text {out }}=0 \mathrm{~Pa}$ is specified (see Figure 2). On all solid walls, a no slip condition is applied, except for the surfaces touching the horizontal line in Figure 2 . Here a symmetry condition is applied. The symmetry condition was validated by modelling two-third of the cell with the parameters for the optimized design presented in section 3.4, and the two models were found to give identical flow profiles.

\subsubsection{Measure of flow uniformity}

Different measures of the flow uniformity/non-uniformity have been used in the literature. Flow uniformity indices, defined by either (3) [16] or (4) [39] have been used by some authors, whereas others have used a non-uniformity index, $F_{n u}[12,32]$. The flow uniformity indices $F_{u}$ and $F_{u 2}$ are identical if all single channel areas (and the density of the gas in each channel) are the same.

For a perfectly uniform flow, the flow uniformity index will be 1 and the non-uniformity index will zero. For non-uniform flow, the indices will be in the interval ]0,1[.

Flow uniformity index

$$
F_{u}=\frac{N \min \left(u_{1} \ldots u_{n}\right)}{\sum_{\mathrm{i}=\mathrm{i}}^{\mathrm{n}} u_{i}}
$$

Flow uniformity index

$$
\begin{gathered}
F_{u 2}=\min \left(\frac{m_{i}}{\bar{m}}\right)=\min \left(\frac{\rho A_{\text {channel }_{i}} u_{i}}{\overline{\rho A_{\text {channel }^{u}}}}\right) \\
\bar{u}_{\iota}=\frac{\sum \rho_{i} A_{\text {channel }, i} u_{i}}{N}
\end{gathered}
$$

Flow non-uniformity index

$$
F_{n u}=\frac{\max \left(u_{1} \ldots u_{n}\right)-\min \left(u_{1} \ldots u_{n}\right)}{\max \left(u_{1} \ldots u_{n}\right)}
$$

Which flow index to use depends on the purpose of the optimization. If it is important that all reactants entering the channel are converted, the operating limits would be determined from the channel with the highest flow. In this case $F_{u}$ should not be used. A high flow in a single channel would only affect $F_{u}$ to a 
minor degree, whereas $F_{n u}$ would be highly affected. If unwanted side reactions take place at high product concentrations, the operating limits would be determined by the channel with the lowest flow. In this case, $F_{u}$ should be used because it is directly affected by the minimum flow.

In SOFC with pure $\mathrm{H}_{2}$, the produced $\mathrm{H}_{2} \mathrm{O}$ might oxidize $\mathrm{Ni}$ to $\mathrm{NiO}$ at high $\mathrm{H}_{2} \mathrm{O}$ concentrations and in SOEC mode, during $\mathrm{CO}_{2}$ and co-electrolysis, solid carbon might form via the Boudouard reaction at high product concentrations [3,41-43]. The current model is therefore optimized with respect to $F_{u}$.

\section{$2.3 \quad$ Mesh and solver settings}

The mesh was build using cuboids in the parallel channels and tetrahedrons everywhere else. The crosssections of the parallel channels were divided into squares, from which the cuboids were created by sweeping the channels. The size of the squares was found by dividing the height and the width of the channel with an integer, where a value greater than 7 was found not to influence the results. The sweeping was conducted using COMSOL's built-in sweep function with the predefined "Coarser" setting. This resulted in cuboids with a size of approx. $5.3 \mathrm{~mm} \times 0.14 \mathrm{~mm} \times 0.04 \mathrm{~mm}$.

The tetrahedrons were created using COMSOL's built-in tetrahedral function with the predefined "Finer" setting and a z-direction scale of 2 . All other settings were kept at standard values.

The mesh was tested by coarsening and refining the predefined settings, and it was found that a further refining than the above resulted in change of less than $0.05 \%$ to the $F_{u}$ value.

The simulations were carried out with the MUMPS solver with the fully coupled constant Newton method (damping factor $=1$ ). All other solver settings were kept at their default values (e.g. the relative tolerance was 0.001).

The average velocity in each channel was extracted using COMSOL's built-in average component coupling function.

\section{Results and discussion}

\subsection{Scope of optimization}

The geometry presented in Figure 1 has a large range of optimizations. The number of inlet holes and channels could be changed, the geometry of the distributor and channels could be changed and a completely different design of the distributor could also be used. In order to limit the optimization possibilities, the scope of the optimization was restricted to values of the parameters $w_{c c}, w_{s c}$ and $w_{b}$. This has several advantages: The purge flow is unaffected and the same cells, seals and external pipe connections can be used. In the following, the effect of the parameters will be illustrated, an optimized design will be constructed, the effect on reaction extent will be calculated and the effect of manufacturing tolerances on the optimized design will be evaluated. Figures showing the velocity field and pressure distribution are available as supplementary material. 


\subsection{Effect of gas distributor dimensions}

The influence of the dimensions of the gas distributor was investigated by changing $w_{s c}$ and $w_{c c}$ (see insert on Figure 3). From the geometry, it is clear that when $w_{s c}<w_{c c}$, the outer channels will obtain a significantly lower flow than the center channels, leading to a poor flow distribution. The parameter $\alpha$ is therefore introduced, with the constraint $\alpha>1$ :

$$
\alpha=w_{s c} / w_{c c}
$$

Figure 3a shows the effect on $F_{u}$ of changing $w_{c c}$ and $\alpha$. The figure shows that a maximum in the flow uniformity exists for an intermediate value of $\alpha$. The reason for this is that at lower $\alpha$ levels, the outer channels (channel 1-4) obtain less flow than the center channels. Increasing $\alpha$ increases the flow to the outer channels and reduces the flow to the center channels. However, as $\alpha$ increase above a certain value the flow reduction in the center channels only causes an increase of the flow to channel 5 and 12 (Figure 3b). The value of $\alpha$ at which the flow uniformity is maximized, decreases with $w_{c c}$ from 4-5 at $w_{c c}=0.4 \mathrm{~mm}$, to 2 at $w_{c c}=1 \mathrm{~mm}$. For $w_{c c}=0.2$ and $0.3 \mathrm{~mm}$ the optimum $\alpha$ is lower than that at $0.4 \mathrm{~mm}$. Furthermore, for $w_{c c}=0.2 \mathrm{~mm}$, a sharp optimum is observed $(\alpha=2.5)$ and for $w_{c c}=0.3$ and $0.4 \mathrm{~mm}$ the flow uniformity reached a plateau. However, if $\alpha$ is further increased, the flow uniformity decreases for $w_{c c}=0.3$ and 0.4 $\mathrm{mm}$ as well (not shown). The sharp optimum for $w_{c c}=0.2 \mathrm{~mm}$ is explained by the fact that at such small width the inlet pressure is not enough to push sufficient gas to the center channels when $\alpha>2.5$, even though some gas will be forced from the side channels, around the distributor, into the center channels. The resulting flow in the center channels is therefore lower than that of the side channels (especially channel 5).

Overall, the maximum obtainable value of $F_{u}$ is located at $w_{c c} 0.3$ and $\alpha=3.5$ when $w_{b}$ is fixed at $2 \mathrm{~mm}$. 

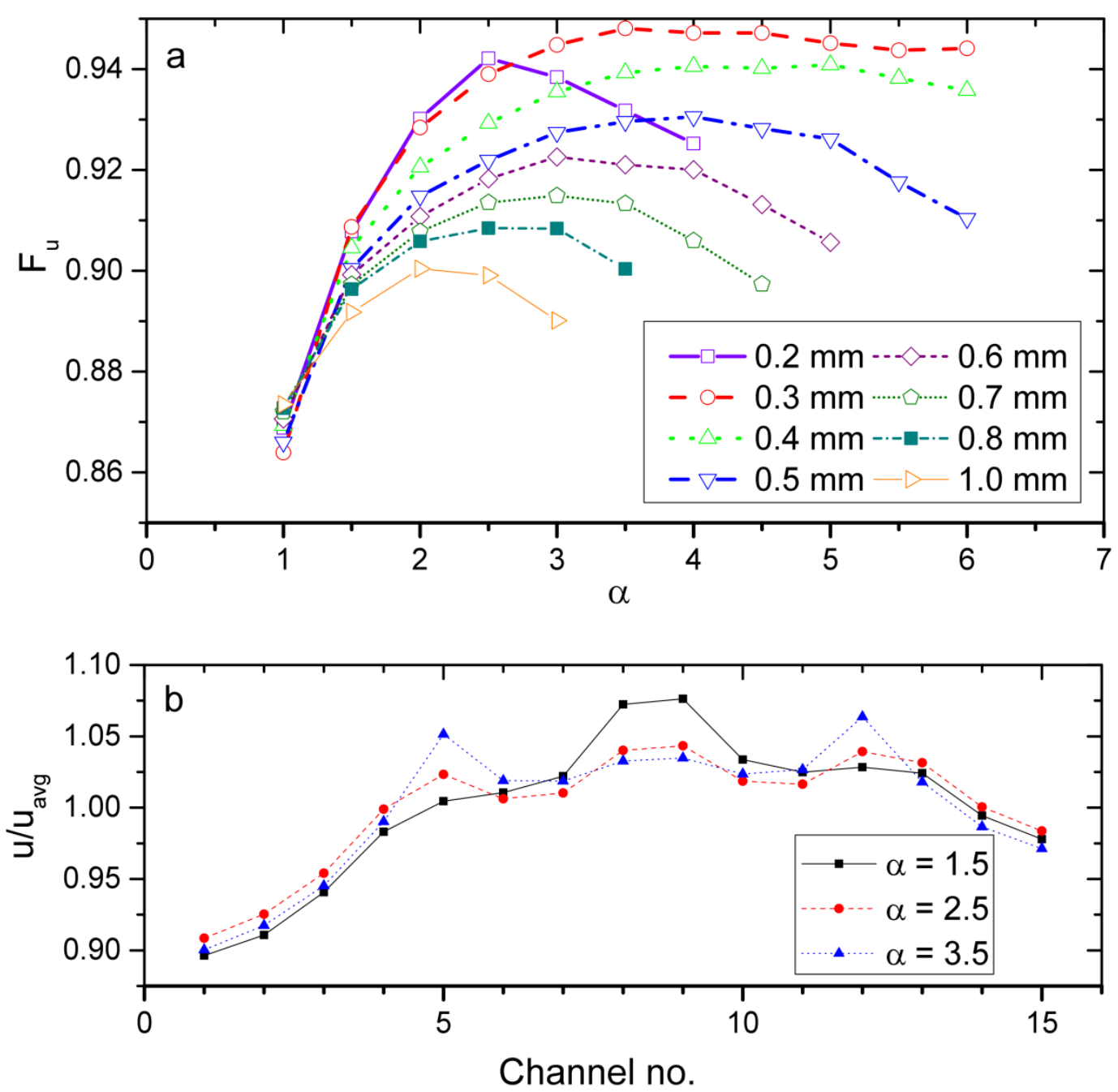

Figure 3: Effect of gas distributor dimensions. a) $F_{u}$ as function of $\alpha$ for different $w_{c c}$ values $(0.20 \mathrm{~mm}$ to $1 \mathrm{~mm})$. b) Normalized flow in each channel for $w_{c c}=0.6 \mathrm{~mm}$ at different values of $\alpha$. In both figure $a$ and $b, w_{b}$ was fixed at $2 \mathrm{~mm}$.

\subsection{Effect of increasing the header width}

To further increase the flow uniformity the influence of header width, $w_{b}$, before channels 1-4 and 13-15 (see insert on Fig. 3), was investigated (Figure 4a). The ribs between channel 5 and 6 and between 11 and 12 are not changed. This means that these two ribs act as constrictions for the side channel flow to enter the center channels. The combinations of $w_{c c}$ and $\alpha$ were based on the maximum points in Figure 3 and the optimum value of $w_{b}$ was found to vary with $w_{c c}$ and $\alpha$. Increasing $w_{b}$ leads to more flow in channel 1-4 and channel 12-15 (Figure 4b). Since especially the flow in the outer channels is low when $w_{b}$ is equal to $2 \mathrm{~mm}$, increasing $w_{b}$ increases the flow uniformity, until the flow in channel 6-11 becomes lower than the flow in channel 1-4. 

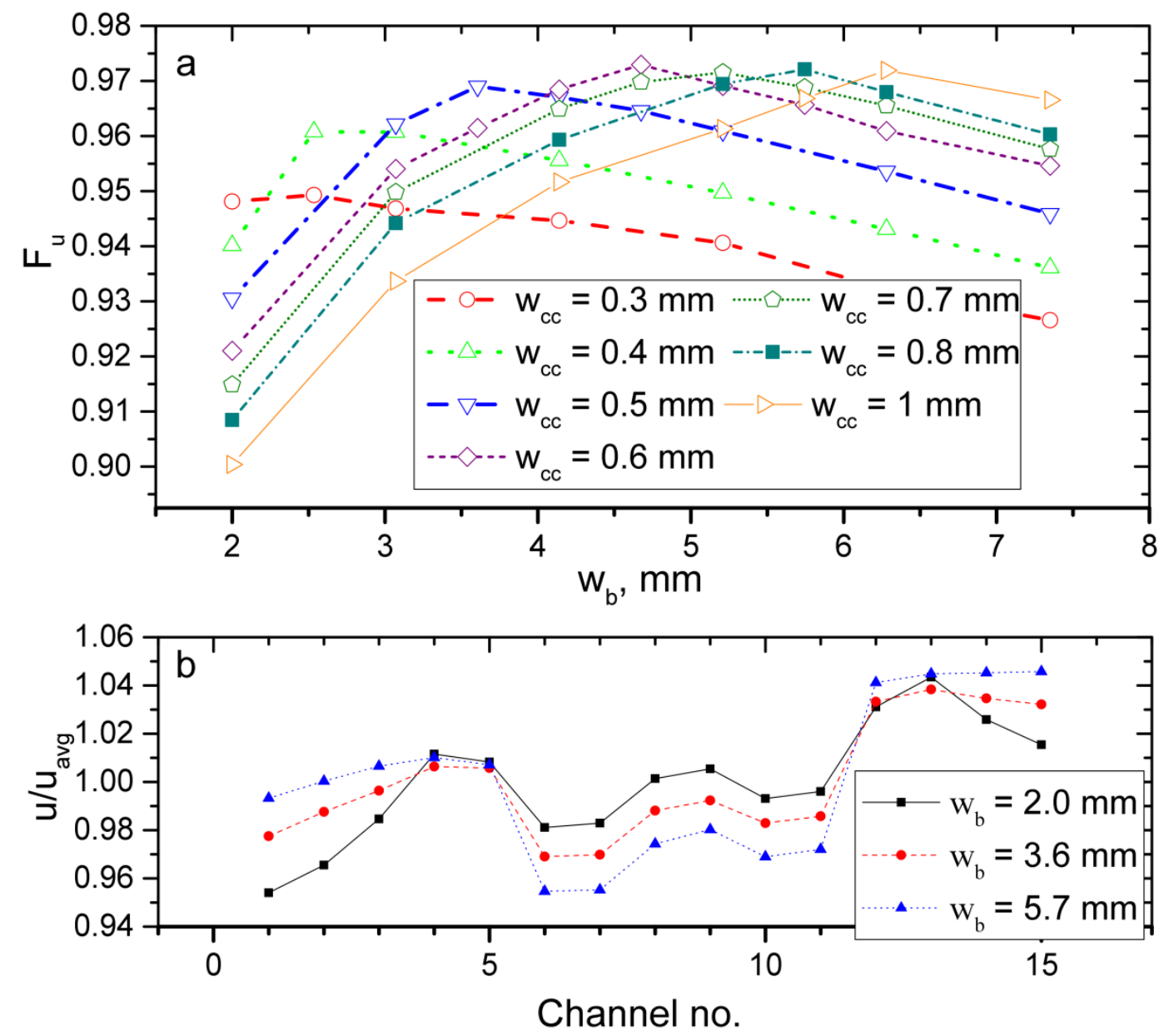

Figure 4. Effect of $w_{b}$. a) $F_{u}$ as function of $w_{b}$ for the optimum points $\left(\left\{w_{c c}, \alpha\right\}=\{0.2 \mathrm{~mm}, 2.5 ; 0.3 \mathrm{~mm}, 3.5 ; 0.4 \mathrm{~mm}, 4 ; 0.5 \mathrm{~mm}, 4\right.$; $0.6 \mathrm{~mm}, 3 ; 0.7 \mathrm{~mm}, 3 ; 0.8 \mathrm{~mm}, 2.5 ; 1 \mathrm{~mm}, 2\}$ ) found in Figure 3. b) Normalized flow in each channel for $\mathrm{w}_{\mathrm{cc}}=0.6 \mathrm{~mm}, \alpha=2.5$ and different values of $w_{b}$.

\subsection{Optimal design}

To investigate the combined effect of the three parameters, bounds for the three parameters were defined (Table 1) and the parameter space was explored using Monte Carlo simulations. The Monte Carlo method was selected to reduce the risk of finding a local maximum point and additionally has the advantage that all the calculations could be performed in parallel, i.e. using a computer cluster.

Table 1. Parameter space

\begin{tabular}{rll}
\hline Parameter & Lower bound & Upper bound \\
\hline $\mathrm{w}_{\mathrm{cc}, \mathrm{mm}}$ & 0.2 & 1.2 \\
$\alpha$ & 1.5 & 6 \\
$\mathrm{w}_{\mathrm{b}, \mathrm{mm}}$ & 2 & 8.5 \\
\hline
\end{tabular}

300 Monte Carlo simulations were performed and the optimal design (highest $F_{u}$ value) was found to be located at $w_{c c}, \alpha$ and $w_{b}$ equal to $0.9 \mathrm{~mm}, 4.66$ and $7.2 \mathrm{~mm}$, respectively, with $F_{u}=0.978$. The normalized flow in each channel is plotted in Figure 5 . It can be seen that the flow is close to being identical for all 
channels. Channel 1 still receives the least amount of flow and channel 5, 12-13 the most. However, the deviations are now very small compared to those in Figure $3 \mathrm{~b}$ and Figure $4 \mathrm{~b}$.

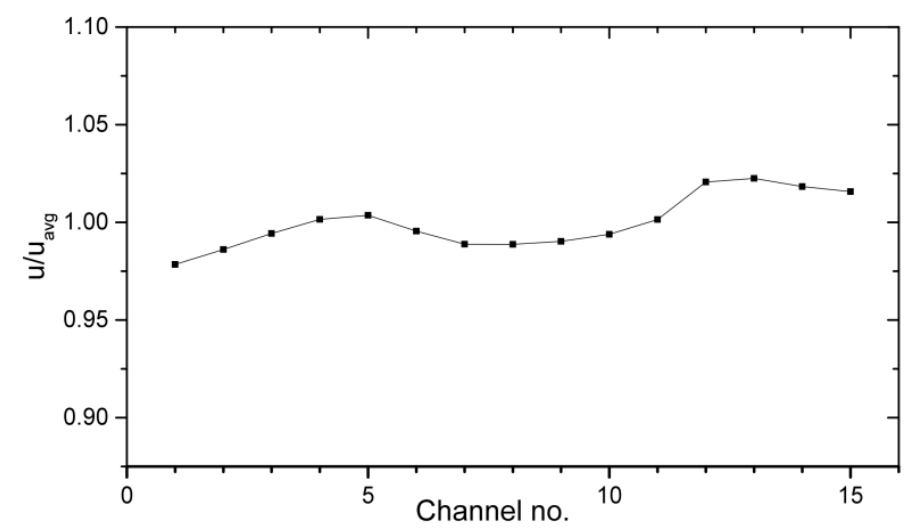

Figure 5. Normalized flow in each channel for the optimized design ( $w_{c c}, \alpha$ and $w_{b}=0.9 \mathrm{~mm}, 4.66,7.2 \mathrm{~mm}$ ).

The uniformity in flow can also be seen in the pressure. Figure 6 shows the pressure drop across channel 1 and the differences between channel 1 and channel 5, 8 and 15, respectively. It can be seen that the pressure differences for the channels are small. It can also be seen that approximately one-tenth of the pressure drop is taking place in the inlet and outlet manifold (approx. 10 Pa pressure drop in each). The pressure is investigated further in the next section.
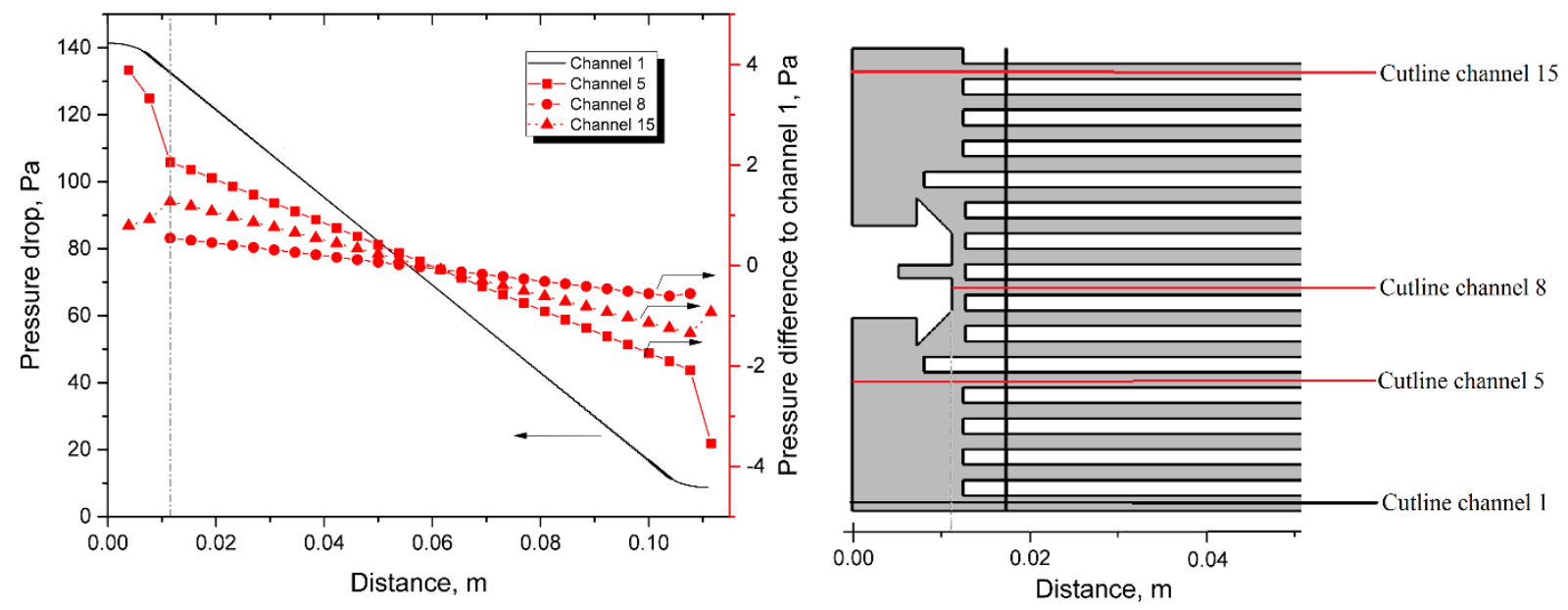

Figure 6 a) Left: Pressure profile for the optimized design ( $w_{c c}, \alpha$ and $w_{b}$ equal to $0.9 \mathrm{~mm}, 4.66$ and $7.2 \mathrm{~mm}$, respectively and $F_{u}=$ 0.978) for channel 1 (left ordinate). The pressure differences between channel 1 and channel 5, 8, 15, respectively, are also plotted (right ordinate). b) Right: Illustration of the cutlines used to create the pressure profiles.

Other designs with similar $F_{u}$ values were also found. To illustrate this, the designs were plotted in Figure 7. In the figure, the data points are projected onto two-dimensional planes. Figure 7a contains all 300 data points, and Figure $7 \mathrm{~b}$ contains only the data points with $F_{U}>0.97$. The value of 0.97 was selected to include a sufficient number of data points to illustrate the correlation between the parameters, while the rest of the data points was excluded for clarity. From the figure it can be seen that there is a correlation between $w_{c c}$ and $w_{b}$ and to a minor extent between $w_{s c}$ and $w_{b}$. The figure shows that an increase in $w_{c c}$ (which leads to more flow in the center channels), can be compensated for by an increase in $w_{b}$. When $w_{b}$ is around 4 $\mathrm{mm}$, the optimum $w_{s c}$ value is around $2.5-3 \mathrm{~mm}$. As $w_{b}$ increase, the span of optimum values for $w_{s c}$ 
increases to $2.5-4.5 \mathrm{~mm}$. This means that as long as the combination of $w_{c c}$ and $w_{b}$ is reasonable, the exact value of $w_{s c}$ is of less importance (as long as it is within the span defined above).

The model is simplified (isothermal, non-reacting and incompressible flow), meshed with a certain refinement and geometrically restricted to the cell, thus an optimal design for non-isothermal, reacting and compressible flow may differ somewhat from the optimized result under simplified conditions Also, since the performance in terms of flow uniformity is almost identical for the local maxima, a preferred design can be chosen by evaluating other properties than the flow uniformity, such as the total pressure drop over the cell.
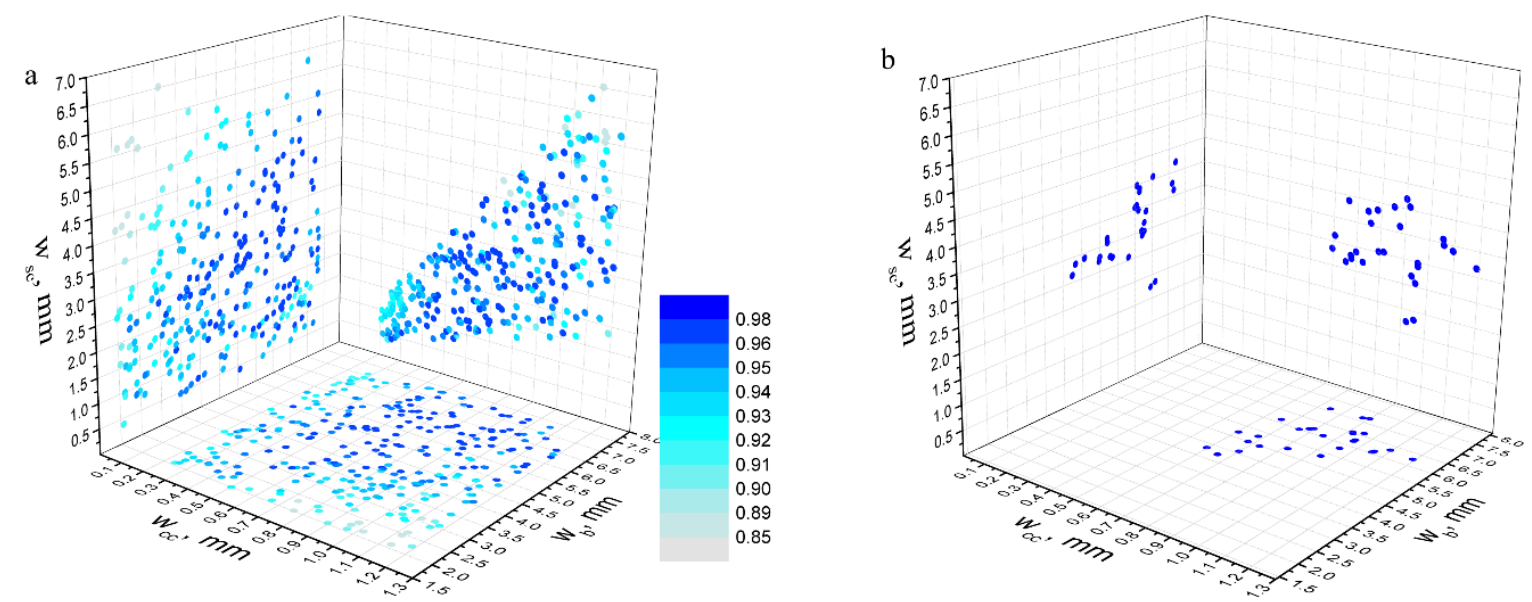

Figure 7. Data points from the Monte Carlo optimization projected onto two-dimensional planes: a) all data points shown, the color map shows the $F_{u}$ value of each data point. b) Only the data points with $F_{u}>0.97$.

\subsection{Underlying factors}

As stated previously the purpose of the distributor (and also header width) is to distribute the gas evenly to all the parallel channels. For the optimized design, it can be seen (Figure 6b) that the lengths of all the channels are approx. the same and that the pressure difference within the header section (i.e. excluding the gas distributor) is less than $4 \mathrm{~Pa}$ (Figure 6a). Since the pressure applied to each channel and the channel length is approx. the same, the resulting flow will also be close to identical and a high $F_{u}$ value will be obtained.

When the parallel channels have a varying length, the pressure in the header must be higher for long channels compared to short channels. However, it is hard/sometimes impossible to get a precise nonuniform pressure distribution in the header section. Figure 3 illustrates how only a local-maximum, for the design shown in Figure 1, can be achieved with parallel channels of uneven length. Parallel channels of uneven length may be necessary when maximizing the active area, but from a flow point-of-view parallel channels with identical length are preferred. 
Table 2 lists the average pressure, standard deviation of the inlet pressure to each channel relative to the average pressure $\left(\sum\left(p_{c, i}-p_{\text {avg }}\right) / N\right)$, pressure drop ratio (pressure drop in the parallel channels over the total pressure drop) and $F_{u}$ for several cases (rows 1-6 are also shown in Figure $3 \mathrm{~b}$ and Figure $4 \mathrm{~b}$ ).

Table 2. Pressure and flow uniformity parameters for different designs. $\mathbf{w}_{\mathrm{cc}}, \mathbf{w}_{\mathrm{sc}}$ and $\mathbf{w}_{\mathrm{b}}$ in $\mathbf{m m}$, pressure and relative standard deviation in $\mathrm{Pa}$, all others are unitless.

\begin{tabular}{|c|c|c|c|c|c|c|c|}
\hline \multirow[b]{2}{*}{$w_{c c}$} & \multicolumn{2}{|c|}{ Case } & \multirow[b]{2}{*}{$\mathrm{wb}_{\mathrm{b}}$} & \multirow{2}{*}{$\begin{array}{l}\text { Average pressure before } \\
\text { parallel channels }\end{array}$} & \multirow{2}{*}{$\begin{array}{l}\text { Relative Standard } \\
\text { deviation }\end{array}$} & \multirow[t]{2}{*}{$\Delta \mathrm{P}_{\text {channels }} / \Delta \mathrm{P}_{\text {total }}$} & \multirow[t]{2}{*}{$F_{u}$} \\
\hline & $W_{s c}$ & $\alpha$ & & & & & \\
\hline 0.6 & 0.9 & 1.5 & 2.0 & 121 & 1.8 & 0.61 & 0.899 \\
\hline 0.6 & 1.5 & 2.5 & 2.0 & 127 & 2.6 & 0.69 & 0.918 \\
\hline 0.6 & 2.1 & 3.5 & 2.0 & 130 & 2.9 & 0.74 & 0.921 \\
\hline 0.6 & 1.5 & 2.5 & 2.0 & 125 & 2.6 & 0.67 & 0.918 \\
\hline 0.6 & 1.5 & 2.5 & 3.6 & 126 & 2.3 & 0.68 & 0.957 \\
\hline 0.6 & 1.5 & 2.5 & 5.7 & 127 & 1.8 & 0.69 & 0.967 \\
\hline 0.6 & 1.5 & 2.5 & 7.35 & 125 & 1.5 & 0.65 & 0.955 \\
\hline \multicolumn{4}{|c|}{ Optimized design } & 139 & 0.9 & 0.85 & 0.978 \\
\hline
\end{tabular}

It can be seen that when $\alpha$ is increased (row 1-3), the average pressure before the channels is also increased. This increase the $\Delta \mathrm{P}_{\text {channels }} / \Delta \mathrm{P}_{\text {total }}$ ratio and also $F_{u}$. The reason for this is that the cross section of the distributor becomes larger and the pressure drop over it therefore decreases. From row 4-7 it can be seen that when the header width is increased, the pressure drop ratio does not change much, but the relative standard deviation decreases and $F_{u}$ increases, until a certain value of $w_{b}$ (here between 5.7 and $7.35 \mathrm{~mm}$ ). This is because the length of the channels becomes more uniform and the flow resistance in the header decreases due to the larger value of $w_{b}$. After a certain value of $w_{b}$, the pressure drop ratio decreases (since more flow is going through the side channel, the pressure drop in the header section increases). This can also be seen more generally in Figure 7 and section 3.4, where a correlation between $w_{c c}$ and $w_{b}$ is described. To reach an optimized design (row 8), the pressure must be uniform (low standard deviation) and the $\Delta \mathrm{P}_{\text {channels }} / \Delta \mathrm{P}_{\text {total }}$ must be high.

It is commonly acknowledged that the pressure drop in the manifold should be significantly lower than that over the cells in a stack to ensure a uniform flow distribution to the cells $[16,32,39,40]$. This is analogous to obtaining a uniform flow in industrial fixed bed reactors and multiple tubular reactors (after the pressure drop in each tube has been adjusted to a common value). For such reactors, a uniform flow can be obtained as long as the pressure drop in the inlet and outlet hood is lower (more than one order of magnitude) than the pressure drop in the tubes [44-46]. Plotting $F_{U}$ as function of pressure drop ratio (added as supplementary material) shows that high $F_{u}$ values can only be obtained with high pressure drop ratio and that the length of the channels should be approx. identical ( $W_{b}$ should be high). 
Based on this, our recommendation for designing a distributor for parallel channels is to use parallel channels with equal length and ensure that the pressure drop ratio is high (preferably the pressure drop in the channels should be one order of magnitude higher can that of the distributor). Similarly, for U- and Ztype designs, the pressure drop in the channels should be significantly higher compared to the manifold/header section.

\subsection{Tolerance to errors in manufacturing}

During manufacturing the production of the geometries will be within certain tolerances, e.g. defined in industry standards such as ISO 2768-1. However, minor changes in the dimensions of the distributor might alter the flow significantly. According to ISO 2768 - 1 a tolerance of $\pm 0.05 \mathrm{~mm}$ is normally a permissible deviation when working with linear dimensions up to $3 \mathrm{~mm}$ in the "fine" tolerance class. Based on the optimized design ( $w_{c c}, \alpha$ and $w_{b}$ equal to $0.9 \mathrm{~mm}, 4.66$ and $7.2 \mathrm{~mm}$, respectively) all combinations of $w_{c c}$, $w_{s c}$, and $w_{b} \pm 0.05 \mathrm{~mm}$ were tested and the lowest value of $F_{u}$ was found to be 0.976 . When the uncertainty was increased to \pm 0.1 and $\pm 0.2 \mathrm{~mm}$, the lowest value of $F_{u}$ was found to be 0.975 and 0.970 , respectively. The design of the gas distributor is therefore robust towards deviations in the geometry caused by tolerance errors in the manufacturing of up to twice of the value allowed in ISO 2768-1.

\subsection{Effect of flow rate}

The effect of flow rate on the flow uniformity and pressure drop was investigated (Figure 8) and it was found that the effect on flow uniformity was small, whereas the pressure drop increased linearly with the flow rate. The result shows that the design is capable of handling quite different flows without significant changes in the flow uniformity. This is important for an SOC operating under varying conditions. Examples of this include SOFCS operating with changing load depending on the demand or SOECs used for storing excess electrical energy in chemical species. A similar response was observed for the other designs (not shown). Investigation of the pressure profiles at the high flow rates (not shown) showed that the decline in flow uniformity was due to different changes in the pressure drop in the center channel and side channel of the distributor. The pressure drop in the center channel increased more than in the side channels and this caused a large fraction of the flow to move through the side channels and thus relatively less flow is supplied to channels 8 and 9 (see Figure 2) through the center channel of the distributor. So, if the design is

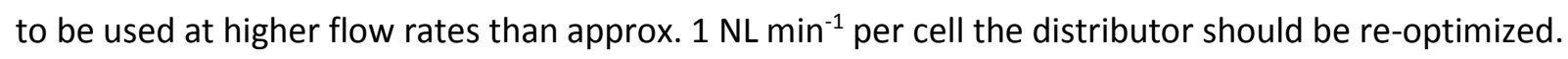




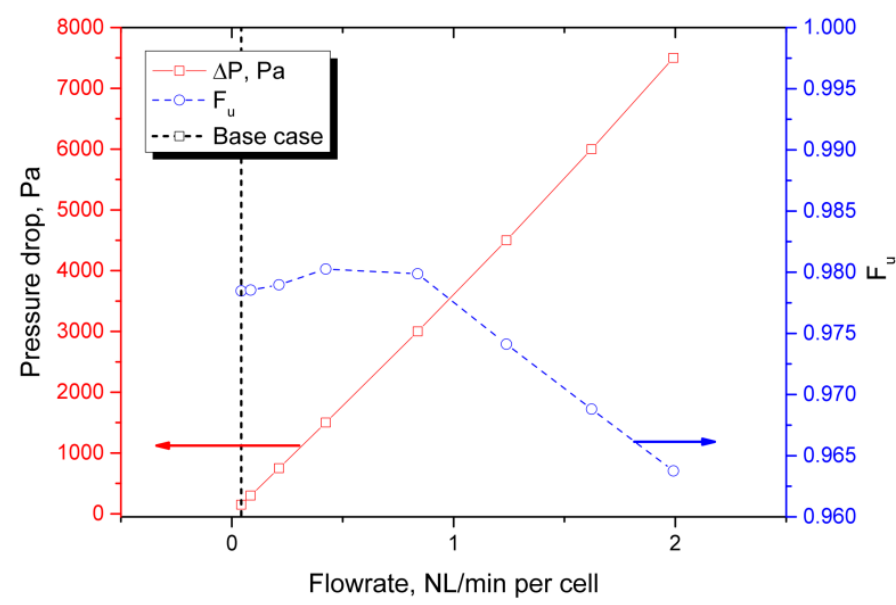

Figure 8. Effect of flow rate on the flow non-uniformity and pressure drop. Vertical line shows optimization base case.

\subsection{Effect of assumptions and flow property parameters}

The simulations have been performed assuming an isothermal, non-reactive and incompressible flow (which is similar to others $[8,32,39,40]$ ). In this section we will explore the validity of results based on these assumptions.

\subsubsection{Effect of the flow parameters (viscosity and gas)}

The optimization was performing using the viscosity and density of air at $1000 \mathrm{~K}$. To verify that the optimized design is also good for other gasses and temperatures, the flow property parameters were calculated at 900,1000 , and $1100 \mathrm{~K}$ for air, $\mathrm{H}_{2}$ and $\mathrm{CO}_{2}$ and corresponding $F_{u}$ values were computed. $\mathrm{H}_{2}$ and $\mathrm{CO}_{2}$ were selected because these are respectively the lightest and heaviest gasses commonly used in SOCs (disregarding hydrocarbons higher than methane). The simulations showed no change in the $F_{u}$ values.

\subsubsection{Effect of non-isothermal conditions}

Bi et al. [39] found that, when applying a linear temperature increase of $200 \mathrm{~K}$ between the inlet and the outlet of a SOFC and assuming a uniform rate of the chemical reactions across the channels, the difference in flow rate distribution compared to the isothermal and non-reacting flow case was less than $1 \%$. Using similar conditions as $\mathrm{Bi}$ et al. $\left(\Delta \mathrm{T}=200 \mathrm{~K}\right.$ from $650{ }^{\circ} \mathrm{C}$ to $850{ }^{\circ} \mathrm{C}, 65 \% \mathrm{w} / \mathrm{w} \mathrm{H}, 35 \% \mathrm{w} / \mathrm{w} \mathrm{H}_{2} \mathrm{O}, 85 \%$ conversion and an uniform rate) we found a difference of $F_{u}$ of less than $0.03 \%$.

Often a non-linear temperature profile between the inlet and outlet is observed in SOC, especially if a cross- or counter flow is used, or if the heat transfer from side of the cell to the surroundings is significant [47-50]. In the literature temperature differences between the edge and the center of the cell has been reported to be in the range of $5-10 \mathrm{~K} \mathrm{~cm}^{-1}$ depending on the operating conditions and design in SOFC mode [49-52]. In SOEC mode the cell can be run endothermic, thermo-neutral, and exothermic which means that the temperature in the center of the cell can either be lower, the same or higher than the edge. In the literature values in the range of -2 to $10 \mathrm{~K} \mathrm{~cm}^{-1}$ has been reported [53]. Using an in-house model (not presented) we obtained values in the same range.

\subsubsection{Effect of reaction present}

To investigate if the temperature difference in the $y$-direction (see Figure 1 and Figure 2 for axis orientation) is affecting the flow uniformity, we applied a temperature gradient of -5 to $15 \mathrm{~K} \mathrm{~cm}^{-1}$ in the $y$ - 
direction for the channels and fixed the temperature at the edge to $1000 \mathrm{~K}$. When air was used as the fluid the effect on $F_{u}$ was less than $1 \%$. It would be more correct to include the effect of the temperature on the current density also. However, the relationship between the current density and temperature is not straightforward and a rigorous calculation of the current density is outside the scope of this article. Instead of a rigorous calculation, we have used the Butler-Volmer equation to approximately calculate the increase of the current density w.r.t. temperature.

The Butler-Volmer equation is given as [54]:

$$
j=j_{0}\left[\exp \left(\frac{a z F n_{a c t}}{R T}\right)-\exp \left(\frac{-a z F n_{a c t}}{R T}\right)\right]
$$

where $J_{o}$ is the exchange current density, $a$ is the charge transfer coefficient, $z$ is the number of electrons transferred and $n_{\text {act }}$ is the activation overpotential. $J_{o}$ can be expressed as [54]

$$
j_{0}=\gamma \exp \left(-\frac{E_{a c t}}{R T}\right)
$$

Using the values given in the literature for the hydrogen-water reaction [54,55], an increase in the current density of $14 \%$ was found when increasing the temperature from $1000 \mathrm{~K}$ to $1010 \mathrm{~K}$ and maintaining the same activation overpotential (0.25 V based on [54]).

In order to include the effect of the temperature on the current distribution, we assumed that the fuel cell was fed with a $65 \% \mathrm{w} / \mathrm{w} \mathrm{H}_{2}, 35 \% \mathrm{w} / \mathrm{w} \mathrm{H}_{2} \mathrm{O}$ gas mixture and $50 \%$ conversion of $\mathrm{H}_{2}$ in SOFC mode. In SOEC mode we assumed a feed with $35 \% \mathrm{w} / \mathrm{w} \mathrm{H}_{2}, 65 \% \mathrm{w} / \mathrm{w} \mathrm{H}_{2} \mathrm{O}$ gas mixture and $50 \%$ conversion of $\mathrm{H}_{2} \mathrm{O}$. The maximum change in $F_{u}$ given these operating conditions was less $1 \%$. This number is based on the assumptions above and the model presented in section 2 . It therefore appears that violation of the assumptions does not change the flow significantly.

However, if an entire cell is modelled instead, a temperature gradient of only $5 \mathrm{~K} \mathrm{~cm}^{-1}$ in the $y$-direction (from $y=0 \mathrm{~mm} 45 \mathrm{~mm}$ (half the cell width) and $-5 \mathrm{~K} \mathrm{~cm}^{-1}$ from $y=45 \mathrm{~mm}$ to $90 \mathrm{~mm}$ ) results in a change in the flow uniformity of more than $1 \%$ (using the same conditions as for the $1 / 3$ of the cell above). The reason for this is that the absolute temperature difference for a whole cell is higher than for $1 / 3$ of the cell.

We therefore advise that the results found in this study are only applied to cells operating with low temperature gradients in the $y$-direction. Such operation is possible. Work regarding the understanding and reducing of heat transfer from the stack to the surroundings has been carried out and is of critical importance when designing SOC systems [6,56-59]. Forschungszentrum Jülich also demonstrated a $5 \mathrm{~kW}$ SOFC stack with very low temperature gradients in the $y$-direction [47]. In SOEC mode, the stack can be operated thermo-neutral, which means that the net heat generation is zero and no temperature gradient in either the $x$ - or $y$-direction is present $[60,61]$ (assuming sufficient insulation of the sides or that the stack is operating in an oven).

\subsection{Effect of flow non-uniformity on possible reaction extent}

The level of flow uniformity limits the maximum allowable extent of conversion of reactants in the cell, before unwanted side-reactions take place. In SOFC the unwanted side-reactions are oxidations of Ni to 
$\mathrm{NiO}$ and in SOEC unwanted side-reactions cause carbon formation (Table 3). Since the current density is (almost) constant in the $y$-direction when the cell is run in co- or counterflow configuration and temperature effects from the side of the stack are ignored, the number of moles converted in each channel will be the same.

Table 3. Unwanted side-reactions in SOFC/SOEC

\begin{tabular}{ll}
\hline Reactions generating $\mathrm{NiO}$ & Reactions generating C \\
\hline $\mathrm{Ni}+\mathrm{CO}_{2} \rightleftarrows \mathrm{NiO}+\mathrm{CO}$ & $2 \mathrm{CO} \rightleftarrows \mathrm{C}(\mathrm{s})+\mathrm{CO}_{2}$ \\
$2 \mathrm{Ni}+\mathrm{CO}_{2} \rightleftarrows 2 \mathrm{NiO}+\mathrm{C}(\mathrm{s})$ & $\mathrm{CH}_{4} \rightleftarrows \mathrm{C}(\mathrm{s})+2 \mathrm{H}_{2}$ \\
$\mathrm{Ni}+\mathrm{CO} \rightleftarrows \mathrm{NiO}+\mathrm{C}(\mathrm{s})$ & $\mathrm{CO}+\mathrm{H}_{2} \rightleftarrows \mathrm{C}(\mathrm{s})+\mathrm{H}_{2} \mathrm{O}$ \\
$2 \mathrm{Ni}+\mathrm{O}_{2} \rightleftarrows 2 \mathrm{NiO}$ & $\mathrm{CO}_{2}+2 \mathrm{H}_{2} \rightleftarrows \mathrm{C}(\mathrm{s})+2 \mathrm{H}_{2} \mathrm{O}$ \\
$\mathrm{Ni}+\mathrm{H}_{2} \mathrm{O} \rightleftarrows \mathrm{NiO}+\mathrm{H}_{2}$ & \\
\hline
\end{tabular}

The number of moles per unit time entering a channel is given by (9). By using this equation, the conversion in each channel and the overall conversion can be expressed by the flow uniformity index and the maximum conversion allowed in the channel with the lowest flow, $X_{\max }$.

Moles reactant per time fed to channel i

$$
\begin{gathered}
n_{i}=\frac{u_{i}}{\bar{u}} \cdot \frac{1}{N} \cdot n_{\text {total }} \\
X_{\text {channel, } i}=\frac{X_{\max } \cdot \min \left(n_{i}\right)}{n_{i}}=\frac{X_{\text {max }} \cdot \min \left(\frac{u_{i}}{\bar{u}}\right)}{\frac{u_{i}}{\bar{u}}}=\frac{X_{\max } F_{u}}{\frac{u_{i}}{\bar{u}}} \\
X_{\text {overall }}=\frac{N \cdot X_{\text {max }} \cdot \min \left(n_{i}\right)}{n_{\text {total }}}=X_{\text {max }} \mathrm{F}_{\mathrm{u}}
\end{gathered}
$$

When side-reactions are ignored, the maximum conversion allowed is $100 \%$. With the optimized gas distributor design (flow uniformity index equal to 0.978) the conversion in the channel with the highest flow is $95.6 \%$ (calc. with (10)) and the overall conversion is $97.8 \%$ (calculated with (11)).

In SOFC the conversion is limited by the risk of oxidizing $\mathrm{Ni}$ to $\mathrm{NiO}$ by the formed products [62]. Oxidation would damage the electrode due to volume expansion, eventually destroying the cell. The oxidation is thermodynamically unfavored when a small amount of reducing species $\left(\mathrm{CO}\right.$ or $\left.\mathrm{H}_{2}\right)$ is present. At $1000 \mathrm{~K}$ the $\mathrm{Ni}$ oxidizing reaction by $\mathrm{H}_{2} \mathrm{O}$ is thermodynamically unfavored when the gas mixture contains at least $0.5 \%$ $\mathrm{H}_{2}$ (using the thermodynamics given in [63]). This means that, for a pure hydrogen fueled SOFC, $\mathrm{X}_{\max }$ is equal to $99.5 \%$, the overall conversion (calculated with (11 and using the flow uniformity index of the optimized gas distributor design) is $97.3 \%$ and the conversion in the channel with the highest flow is 95.2 $\%$. 
During $\mathrm{CO}_{2}$ - and co-electrolysis solid carbon can be formed. The carbon is typically whisker carbon, causing delamination of the electrode and electrolyte. In $\mathrm{CO}_{2}$ electrolysis the carbon formation is thermodynamically favored for conversions above $74.5 \%$ at $1000 \mathrm{~K}$ (using the thermodynamics given in [64]). This means that the overall conversion is limited to $72.9 \%$ and the conversion in the channel with the highest flow is only $71.2 \%$. If a design with less uniform flow is used, e.g. the design in Bi et al. [39], the overall conversion is limited to $67.8 \%$ (for $F_{u}=0.91$ ). This shows that the flow uniformity has a significant effect on the possible overall conversion.

The above calculations are only strictly valid under the assumption of isothermal and non-reacting flow. However, as shown in section 3.8 the results are nevertheless applicable as long as there is no temperature gradient in the $y$-direction.

\section{Conclusion}

The optimal design of a special gas distributor to distribute the feed gas into parallel channels of a solid oxide cell has been investigated with CFD modelling. An optimized design was achieved by changing three geometrical parameters $\left(w_{c c}=0.9 \mathrm{~mm}, \alpha=4.66, w_{b}=7.2 \mathrm{~mm}\right)$ in the gas distributor reaching a flow uniformity index of 0.978 . The optimization was performed using 300 Monte Carlo simulations and a soft maximum was found. Since the maximum is soft, the optimized design can be further tuned by including e.g. pressure drop in the optimization penalty function.

A temperature gradient of $5 \mathrm{~K} \mathrm{~cm}^{-1}$ in the direction perpendicular to the flow in the channels was found to influence the calculated flow uniformity, whereas a temperature gradient in the $x$-direction of up to $15 \mathrm{~K}$ $\mathrm{cm}^{-1}$ did not affect the flow uniformity. Thus, the findings in this study are only valid for cells with low temperature gradients in the $y$-direction.

The design is robust towards variations in the manufacturing process since variations in the optimized parameters of $\pm 0.05 \mathrm{~mm}$ only lower the flow uniformity marginally from 0.978 to not less than 0.976 .

Since flow uniformity dictates the possible overall conversion, the optimized design allows for a higher overall conversion than the non-optimized design. In the optimized gas distributor design, the maximum allowable average conversion (to avoid carbon formation) is only reduced by 2.3 percentage point compared to the situation with ideal flow distribution. In $\mathrm{CO}_{2}$ electrolysis this corresponds to an overall conversion of $72.9 \%$ with the optimized design compared to the theoretical maximum of $74.5 \%$.

\section{Acknowledgments}

This project is a collaboration between the CHEC Research center at DTU Chemical Engineering and Haldor Topsoe A/S and is partially funded by the Danish Industrial Ph.D. Fellowship Programme administered by Innovation Fund Denmark. 


\section{References}

[1] J.B. Hansen, Fuel processing for fuel cells and power to fuels as seen from an industrial perspective, J. Catal. 328 (2015) 280-296. doi:10.1016/j.jcat.2015.04.014.

[2] C.M. Huang, S.S. Shy, H.H. Li, C.H. Lee, The impact of flow distributors on the performance of planar solid oxide fuel cell, J. Power Sources. 195 (2010) 6280-6286. doi:10.1016/j.jpowsour.2010.04.073.

[3] Y. Tao, S.D. Ebbesen, M.B. Mogensen, Carbon Deposition in Solid Oxide Cells during Co-Electrolysis of $\mathrm{H} 2 \mathrm{O}$ and CO2, J. Electrochem. Soc. 161 (2014) F337-F343. doi:10.1149/2.079403jes.

[4] K. Kendall, N.Q. Minh, S.C. Singhal, Chapter 08 - Cell and Stack Designs, High Temp. Solid Oxide Fuel Cells. (2003) 197-228. doi:http://dx.doi.org/10.1016/B978-185617387-2/50025-8.

[5] L.G.J. De Haart, M. Spiller, FUEL CELLS - SOLID OXIDE FUEL CELLS | Gas Distribution, in: J. Garche (Ed.), Encycl. Electrochem. Power Sources, Elsevier, Amsterdam, 2009: pp. 77-87. doi:http://dx.doi.org/10.1016/B978-044452745-5.00253-7.

[6] N.Q. Minh, System designs and applications, in: M. Kendall, Kevin and Kendall (Ed.), HighTemperature Solid Oxide Fuel Cells 21st Century, 2nd ed., Elsevier Ltd., 2016: pp. 283-327. doi:10.1016/B978-0-12-410453-2.00009-9.

[7] J. Jang, W. Yan, H. Li, W. Tsai, Three-dimensional numerical study on cell performance and transport phenomena of PEM fuel cells with conventional flow fields, Int. J. Hydrogen Energy. 33 (2008) 156164. doi:10.1016/j.ijhydene.2007.09.005.

[8] W.L. Huang, Q. Zhu, Flow distribution in U-type layers or stacks of planar fuel cells, J. Power Sources. 178 (2008) 353-362. doi:10.1016/j.jpowsour.2007.12.003.

[9] G. Hu, J. Fan, S. Chen, Y. Liu, K. Cen, Three-dimensional numerical analysis of proton exchange membrane fuel cells (PEMFCs) with conventional and interdigitated flow fields, J. Power Sources. 136 (2004) 1-9. doi:10.1016/j.jpowsour.2004.05.010.

[10] C.-H. Cheng, H.-H. Lin, Numerical analysis of effects of flow channel size on reactant transport in a proton exchange membrane fuel cell stack, J. Power Sources. 194 (2009) 349-359.

doi:10.1016/j.jpowsour.2009.04.075.

[11] M. Hyun, S.-K. Kim, D. Jung, B. Lee, D. Peck, T. Kim, et al., Prediction of anode performances of direct methanol fuel cells with different flow-field design using computational simulation, J. Power Sources. 157 (2006) 875-885. doi:10.1016/j.jpowsour.2006.02.023.

[12] J.M. Jackson, M.L. Hupert, S.A. Soper, Discrete geometry optimization for reducing flow nonuniformity, asymmetry, and parasitic minor loss pressure drops in Z-type configurations of fuel cells, J. Power Sources. 269 (2014) 274-283. doi:10.1016/j.jpowsour.2014.06.136.

[13] W. Xia, Y. Yang, Q. Wang, Effects of operations and structural parameters on the one-cell stack performance of planar solid oxide fuel cell, J. Power Sources. 194 (2009) 886-898.

doi:10.1016/j.jpowsour.2009.06.009.

[14] S. Su, H. He, D. Chen, W. Zhu, Y. Wu, W. Kong, et al., Flow distribution analyzing for the solid oxide fuel cell short stacks with rectangular and discrete cylindrical rib configurations, Int. J. Hydrogen Energy. 40 (2015) 577-592. doi:10.1016/j.ijhydene.2014.10.125.

[15] H.H. He, S.D. Zhang, Q. Zhang, S.C. Su, B. Wang, W.L. Zhang, Investigating on the Flow Distribution of 
a Planar Solid Oxide Fuel Cell Stack, Adv. Mater. Res. 986-987 (2014) 97-100.

doi:10.4028/www.scientific.net/AMR.986-987.97.

[16] W. Bi, D. Chen, Z. Lin, A key geometric parameter for the flow uniformity in planar solid oxide fuel cell stacks, Int. J. Hydrogen Energy. 34 (2009) 3873-3884. doi:10.1016/j.ijhydene.2009.02.071.

[17] J. Duquette, A. Petric, Silver wire seal design for planar solid oxide fuel cell stack, J. Power Sources. 137 (2004) 71-75. doi:10.1016/j.jpowsour.2004.05.038.

[18] J.A. Salvatore, V. Rajamani, A. Dutta, EP2377190 (B1): Uniform Gas Distribution through Channels of SOFC, 2012.

http://worldwide.espacenet.com/publicationDetails/description?CC=EP\&NR=2377190B1\&KC=B1\&F $\mathrm{T}=\mathrm{D} \& \mathrm{ND}=4 \&$ date $=20140806 \& \mathrm{DB}=$ worldwide. espacenet.com\&locale=en_EP (accessed November $26,2015)$.

[19] W. Zhang, P. Hu, X. Lai, L. Peng, Analysis and optimization of flow distribution in parallel-channel configurations for proton exchange membrane fuel cells, J. Power Sources. 194 (2009) 931-940. doi:10.1016/j.jpowsour.2009.05.033.

[20] Y.-P. Chyou, Y.-N. Cheng, K.-F. Lin, US 20070207363 A1: Interconnect set of planar solid oxide fuel cell having flow paths, 2007. https://www.google.com/patents/US20070207363 (accessed November 27, 2015).

[21] C.M. Huang, S.S. Shy, C.H. Lee, On flow uniformity in various interconnects and its influence to cell performance of planar SOFC, J. Power Sources. 183 (2008) 205-213. doi:10.1016/j.jpowsour.2008.04.059.

[22] T. Heiredal-Clausen, C. Buchholtz Frederiksen, Gas Inlet for SOEC Unit, (2014). https://patentscope.wipo.int/search/en/detail.jsf?docld=WO2014177212\&recNum=1\&maxRec=\&of fice=\&prevFilter=\&sortOption=\&queryString=\&tab=PCT+Biblio (accessed July 13, 2015).

[23] L. Wang, H. Liu, Performance studies of PEM fuel cells with interdigitated flow fields, J. Power Sources. 134 (2004) 185-196. doi:10.1016/j.jpowsour.2004.03.055.

[24] W. Yan, S. Mei, C. Soong, Z. Liu, D. Song, Experimental study on the performance of PEM fuel cells with interdigitated flow channels, 160 (2006) 116-122. doi:10.1016/j.jpowsour.2006.01.063.

[25] S. Maharudrayya, S. Jayanti, A.P. Deshpande, Pressure drop and flow distribution in multiple parallel-channel configurations used in proton-exchange membrane fuel cell stacks, J. Power Sources. 157 (2006) 358-367. doi:10.1016/j.jpowsour.2005.07.064.

[26] N. Guo, M.C. Leu, U.O. Koylu, Network based optimization model for pin-type flow field of polymer electrolyte membrane fuel cell, Int. J. Hydrogen Energy. 38 (2013) 6750-6761. doi:10.1016/j.ijhydene.2013.03.066.

[27] X. Li, I. Sabir, Review of bipolar plates in PEM fuel cells: Flow-field designs, Int. J. Hydrogen Energy. 30 (2005) 359-371. doi:10.1016/j.ijhydene.2004.09.019.

[28] A. Hermann, T. Chaudhuri, P. Spagnol, Bipolar plates for PEM fuel cells: A review, Int. J. Hydrogen Energy. 30 (2005) 1297-1302. doi:10.1016/j.ijhydene.2005.04.016.

[29] H. Tawfik, Y. Hung, D. Mahajan, Metal bipolar plates for PEM fuel cell-A review, J. Power Sources. 163 (2007) 755-767. doi:10.1016/j.jpowsour.2006.09.088. 
[30] J. Wang, Theory and practice of flow field designs for fuel cell scaling-up: A critical review, Appl. Energy. 157 (2015) 640-663. doi:10.1016/j.apenergy.2015.01.032.

[31] J. WANG, Pressure drop and flow distribution in parallel-channel configurations of fuel cells: U-type arrangement, Int. J. Hydrogen Energy. 33 (2008) 6339-6350. doi:10.1016/j.ijhydene.2008.08.020.

[32] S. Maharudrayya, S. Jayanti, A.P. Deshpande, Flow distribution and pressure drop in parallel-channel configurations of planar fuel cells, J. Power Sources. 144 (2005) 94-106. doi:10.1016/j.jpowsour.2004.12.018.

[33] J. Wang, H. Wang, Flow-field designs of bipolar plates in PEM fuel cells: Theory and applications, Fuel Cells. 12 (2012) 989-1003. doi:10.1002/fuce.201200074.

[34] A. Arvay, J. French, J.-C. Wang, X.-H. Peng, A.M. Kannan, Nature inspired flow field designs for proton exchange membrane fuel cell, Int. J. Hydrogen Energy. 38 (2013) 3717-3726. doi:10.1016/j.ijhydene.2012.12.149.

[35] C.-H. Chen, S.-P. Jung, S.-C. Yen, Flow distribution in the manifold of PEM fuel cell stack, J. Power Sources. 173 (2007) 249-263. doi:10.1016/j.jpowsour.2007.05.007.

[36] X. Yu, B. Zhou, A. Sobiesiak, Water and thermal management for Ballard PEM fuel cell stack, J. Power Sources. 147 (2005) 184-195. doi:10.1016/j.jpowsour.2005.01.030.

[37] Y. Zong, B. Zhou, A. Sobiesiak, Water and thermal management in a single PEM fuel cell with nonuniform stack temperature, J. Power Sources. 161 (2006) 143-159.

doi:10.1016/j.jpowsour.2006.02.107.

[38] A. Faghri, Z. Guo, Challenges and opportunities of thermal management issues related to fuel cell technology and modeling, Int. J. Heat Mass Transf. 48 (2005) 3891-3920.

doi:10.1016/j.ijheatmasstransfer.2005.04.014.

[39] W. Bi, J. Li, Z. Lin, Flow uniformity optimization for large size planar solid oxide fuel cells with U-type parallel channel designs, J. Power Sources. 195 (2010) 3207-3214. doi:10.1016/j.jpowsour.2009.11.127.

[40] J.-H. Koh, H.-K. Seo, C.G. Lee, Y.-S. Yoo, H.C. Lim, Pressure and flow distribution in internal gas manifolds of a fuel-cell stack, J. Power Sources. 115 (2003) 54-65. doi:10.1016/S03787753(02)00615-8.

[41] J. Kirtley, A. Singh, D. Halat, T. Oswell, J.M. Hill, R.A. Walker, In Situ Raman Studies of Carbon Removal from High Temperature Ni-YSZ Cermet Anodes by Gas Phase Reforming Agents, J. Phys. Chem. C. 117 (2013) 25908-25916. doi:10.1021/jp408192e.

[42] V. Alzate-Restrepo, J.M. Hill, Carbon deposition on Ni/YSZ anodes exposed to CO/H2 feeds, J. Power Sources. 195 (2010) 1344-1351. doi:10.1016/j.jpowsour.2009.09.014.

[43] A. Faes, A. Hessler-Wyser, A. Zryd, J. Van Herle, A review of RedOx cycling of solid oxide fuel cells anode, Membranes (Basel). 2 (2012) 585-664. doi:10.3390/membranes2030585.

[44] V.E. Senecal, Fluid Distribution in Process Equipment, Ind. Eng. Chem. 49 (1957) 993-997. doi:10.1021/ie50570a031.

[45] A. Cybulski, G. Eigenberger, A. Stankiewicz, Operational and Structural Nonidealities in Modeling and 
Design of Multitubular Catalytic Reactors, Ind. Eng. Chem. Res. 36 (1997) 3140-3148. doi:10.1021/ie960596s.

[46] G. Eigenberger, W. Ruppel, Catalytic Fixed-Bed Reactors, Ullmann's Encycl. Ind. Chem. (2012). doi:10.1002/14356007.b04_199.pub2.

[47] B. Emonts, IWV-3 Report 2005: Future as a challenge, in: Schriften Des Forschungszentrums Jülich. R. Energietechnik / Energy Technol., Forschungszentrum, Zentralbibliothek, Jülich, 2005. http://juser.fz-juelich.de/record/46935.

[48] K.P. Recknagle, R.E. Williford, L.A. Chick, D.R. Rector, M.A. Khaleel, Three-dimensional thermo-fluid electrochemical modeling of planar SOFC stacks, J. Power Sources. 113 (2003) 109-114. doi:10.1016/S0378-7753(02)00487-1.

[49] Y.P. Chyou, T.D. Chung, J.S. Chen, R.F. Shie, Integrated thermal engineering analyses with heat transfer at periphery of planar solid oxide fuel cell, J. Power Sources. 139 (2005) 126-140. doi:10.1016/j.jpowsour.2004.07.001.

[50] J.S. Herring, J.E. O’Brien, C.M. Stoots, G.L. Hawkes, J.J. Hartvigsen, M. Shahnam, Progress in hightemperature electrolysis for hydrogen production using planar SOFC technology, Int. J. Hydrogen Energy. 32 (2007) 440-450. doi:10.1016/j.ijhydene.2006.06.061.

[51] C.-K. Lin, T.-T. Chen, Y.-P. Chyou, L.-K. Chiang, Thermal stress analysis of a planar SOFC stack, J. Power Sources. 164 (2007) 238-251. doi:10.1016/j.jpowsour.2006.10.089.

[52] M. Peksen, A. Al-Masri, L. Blum, D. Stolten, 3D transient thermomechanical behaviour of a full scale SOFC short stack, Int. J. Hydrogen Energy. 38 (2013) 4099-4107.

doi:10.1016/j.ijhydene.2013.01.072.

[53] G. Hawkes, J. O'Brien, C. Stoots, S. Herring, M. Shahnam, Thermal and Electrochemical Three Dimensional CFD Model of a Planar Solid Oxide Electrolysis Cell, Heat Transf. Vol. 4. (2005) 27-36. doi:10.1115/HT2005-72565.

[54] M. Ni, M. Leung, D. Leung, Parametric study of solid oxide steam electrolyzer for hydrogen production, Int. J. Hydrogen Energy. 32 (2007) 2305-2313. doi:10.1016/j.ijhydene.2007.03.001.

[55] S.H. Chan, Z.T. Xia, Polarization effects in electrolyte/electrode-supported solid oxide fuel cells, J. Appl. Electrochem. 32 (2002) 339-347. doi:10.1023/A:1015593326549.

[56] D.L. Damm, A.G. Fedorov, Radiation heat transfer in SOFC materials and components, J. Power Sources. 143 (2005) 158-165. doi:10.1016/j.jpowsour.2004.11.063.

[57] S. Tang, A. Amiri, P. Vijay, M.O. Tadé, Development and validation of a computationally efficient pseudo 3D model for planar SOFC integrated with a heating furnace, Chem. Eng. J. 290 (2016) 252262. doi:10.1016/j.cej.2016.01.040.

[58] M. Spinnler, Studies on high-temperature multilayer thermal insulations, Int. J. Heat Mass Transf. 47 (2004) 1305-1312. doi:10.1016/j.ijheatmasstransfer.2003.08.012.

[59] M. Spinnler, E.R.F. Winter, R. Viskanta, T. Sattelmayer, Theoretical studies of high-temperature multilayer thermal insulations using radiation scaling, J. Quant. Spectrosc. Radiat. Transf. 84 (2004) 477-491. doi:10.1016/S0022-4073(03)00264-4. 
[60] M. Ni, Computational fluid dynamics modeling of a solid oxide electrolyzer cell for hydrogen production, Int. J. Hydrogen Energy. 34 (2009) 7795-7806. doi:10.1016/j.ijhydene.2009.07.080.

[61] M. Ni, Modeling of a solid oxide electrolysis cell for carbon dioxide electrolysis, Chem. Eng. J. 164 (2010) 246-254. doi:10.1016/j.cej.2010.08.032.

[62] J. Kuhn, O. Kesler, Method for in situ carbon deposition measurement for solid oxide fuel cells, J. Power Sources. 246 (2014) 430-437. doi:10.1016/j.jpowsour.2013.07.106.

[63] P. Nehter, A high fuel utilizing solid oxide fuel cell cycle with regard to the formation of nickel oxide and power density, J. Power Sources. 164 (2007) 252-259. doi:10.1016/j.jpowsour.2006.08.037.

[64] J. R. Rostrup-Nielsen, Equilibria of decomposition reactions of carbon monoxide and methane over nickel catalysts, J. Catal. 27 (1972) 343-356. doi:10.1016/0021-9517(72)90170-4. 